\title{
Activity patterns of nine phyllostomid bat species in a fragment of the Atlantic Forest in southeastern Brazil
}

\author{
Ludmilla Moura de Souza Aguiar ${ }^{1} \&$ Jader Marinho-Filho ${ }^{2}$ \\ 1 Embrapa Cerrados, Recursos Naturais. Rodovia BR 020, km 18, Caixa Postal 08223, 73301-970 Planaltina, Distrito \\ Federal, Brasil. E-mail: ludmilla@cpac.embrapa.br \\ 2 Departamento de Zoologia, Universidade de Brasília. 70910-900 Brasília, Distrito Federal, Brasil. E-mail: jmarinho@unb.br
}

\begin{abstract}
Seasonal, monthly and hourly activity patterns of nine bat species were studied based on their capture rates at the Reserva Particular do Patrimônio Natural Feliciano Miguel Abdala (RPPN-FMA), Caratinga, Minas Gerais state, southeastern Brazil. The frugivorous and nectarivorous bat species have their activity closely related to the availability of food. Divergence in monthly and hourly activity is discussed for pairs of similar species and the hypothesis of reduction in competition for nectarivorous and frugivorous species are rejected. Further studies on frugivores-plants interactions should be conducted to assess the long term consequences for the whole system at the RPPN-MFA.

KEY WORDS. Chiroptera, Phyllostomidae, resource partitioning, temporal activity.
\end{abstract}

RESUMO. A atividade mensal e horária de nove espécies de morcegos foi estudada a partir das taxas de captura na Reserva Particular do Patrimônio Natural Feliciano Miguel Abdala (RPPN-FMA), Caratinga, Minas Gerais, Brasil. As espécies frugívoras e nectarívoras parecem ter a atividade relacionada à disponibilidade de alimento. Divergências nas atividades mensal e horária são discutidas para pares de espécies similares e a hipótese da redução na competição para as espécies nectarívoras e frugívoras é rejeitada. Estudos adicionais sobre as interações de espécies de frugívoros entre si e com suas plantas de alimentação deveriam ser conduzidos de modo a prever as consequiências de longo prazo destas interações para a manutenção desta comunidade no fragmento da RPPN-MFA.

PALAVRAS CHAVES. Chiroptera, Phyllostomidae, partição de recursos, atividade temporal.

Due to their great biomass and diversity of dietary habits, bats play a fundamental role in the maintenance of ecological processes in tropical forests (FLEMING 1988). Checking the fluctuation in temporal activity patterns of similar species that coexist in a certain environment may elucidate, in some cases, the mechanisms of resource partitioning among species. Flight is an energetically costing activity (NORBERG et al. 1993) and may suffer influences from physiological conditions of each species or environmental fluctuations (ERKERT 1982).

Studies carried out on neotropical frugivorous bats by LA VAL (1970), Reis (1984) and Trajano (1985), took into consideration that the differences in frugivorous bat species activity patterns would be reducing the competition among these species, while other researchers as Heithaus et al. (1975), MarinhoFilho \& Sazima (1989), Muller \& Reis (1992) and Pedro \& Taddei (2002) argue that the differences in activity patterns of frugivorous species could reduce the competition only if it occurred by direct interference during the feeding period. HeirHaus et al. (1975) also suggested that temporal differences in foraging may be important to the nectarivorous species that exploit resources that are renewable along the night.

Data on hourly and monthly activity patterns of nine bat species from the Reserva Particular do Patrimônio Natural Feliciano Miguel Abdala (RPPN-MFA), Caratinga, Minas Gerais state, are reported and discussed in this study. Herein we test the differences of hourly, monthly and seasonal activity curves for some bat species in a fragment of Atlantic Forest in southeastern Brazil.

\section{MATERIAL AND METHODS}

\section{Study site}

The study site was the 'Reserva Particular do Patrimônio Natural Feliciano Miguel Abdala' (RPPN-FMA) (1950'S and $41^{\circ} 50^{\prime} \mathrm{W}, 628 \mathrm{~m}$ altitude), an Atlantic Forest fragment, in Minas Gerais state, southeastern Brazil, formed by a mosaic of vegetation resulting from logging and natural causes (Fig. 1). Since September of 2001 IBAMA has declared the Biological Station of Caratinga and the Montes Claros Farm as a Reserva Particular do Patrimônio Natural (RPPN) Feliciano Miguel Abdala. It

Revista Brasileira de Zoologia 21 (2): 385-390, junho 2004 

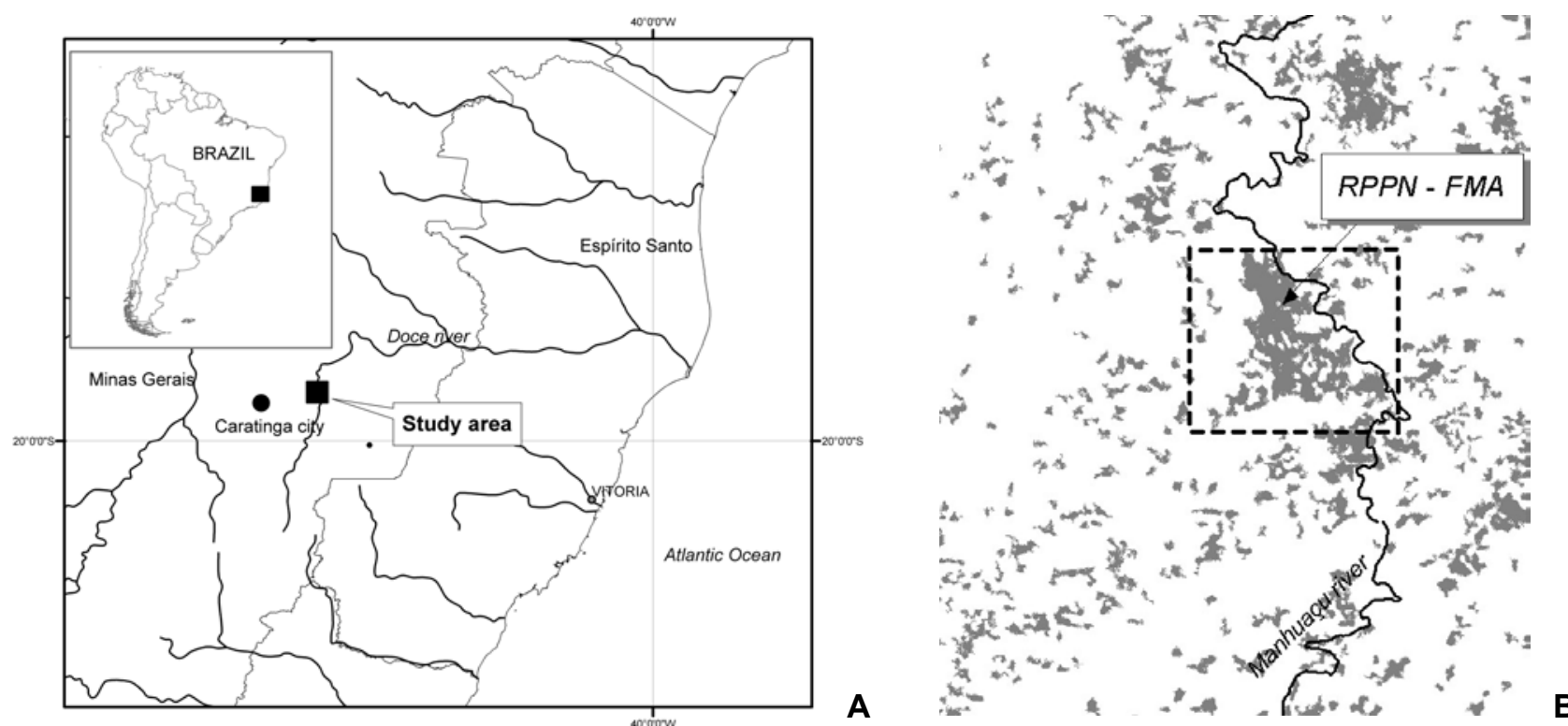

Figure 1. (a) Location of the study area, RPPN Feliciano Miguel Abdala, in Brazil and Minas Gerais State; (b) the gray patches are the Atlantic Forest fragments in the region (based on LandSat TM images acquired in 1996). The RPPN Feliciano Miguel Abdala is the greatest fragment in this region.

was first established to protect a small and isolated population of Brachyteles hypoxanthus (Kulh, 1821) an endangered primate species. This area is covered by 886 hectares of lowland tropical moist forest (HOLDRIDGE 1967) and is located in the central part of the original distribution of the Atlantic Forest biome. Most abundant plant families are Fabaceae, Mimosaceae, Lauraceae, Anacardiaceae, Bignoniaceae, Piperaceae, Moraceae and Cecropiaceae.

The climate is AW (Köppen) tropical mesothermal semi humid (IвGE 1977) with a dry and cooler season from April to September when temperatures may fall to a minimum of $10^{\circ}$, and a rainy and warm season from October to March (mean maximum temperature of $25,4{ }^{\circ} \mathrm{C}$ ). Annual rainfall is around $1.100 \mathrm{~mm}$. During the period of this study, the driest period corresponded to the months of lower temperature, June to August, and the rainiest period occurred from November to February.

\section{Bats}

Ten mist nets (ATX 12 × $2.5 \mathrm{~m}, 35 \mathrm{~mm}$ mesh, four shelves) were set to sample bats monthly, from April 1989 to February 1990, for three consecutive nights in each of the three different sites of the study area. Sampling was never done during the full moon to avoid lunar phobia. A pilot study conducted before yielded very few individuals after the first half of the night and therefore it was decided to open the nets at sunset and close 8 hours later. Nets were tended every 15 minutes, during three days per month in each site and were placed in the same general site but never exactly the same position each time, to avoid bats learning their location (LA VAL \& FITCH 1977).
Captured animals were placed in cloth bags, identified, weighed, measured, and individually marked with numbered plastic ring on the forearm and released. Voucher specimens of all collected species are preserved in 70\% ethanol and deposited in the bat collection of the Universidade Estadual de São Paulo (UNESP) at São José do Rio Preto, São Paulo. Sunset and sunrise times corresponded to data obtained from the Observatório Nacional do Rio de Janeiro, Brazil (1989, 1990). Statistical analyses were performed with Fisher Exact Test, Chi Square and Kolmogorov-Smirnov test (KS) for significance level of 0.05, following ZAR (1984).

A capture effort of 2,649 mist-net-hours was performed over 99 nights of sampling. Although monthly sampling efforts were the same, one month at the end of the rainy season (March) was not sampled. Comparisons of activity patterns were done among similar species of large frugivorous Artibeus lituratus (Olfers, 1818), Artibeus fimbriatus Gray, 1838 and Artibeus obscurus (Schinz, 1821); middle sized frugivorous species, Carollia perspicillata (Linnaeus, 1758), Sturnira lilium (E. Geoffroy, 1810) and Platyrrhinus lineatus (E. Geoffroy, 1810); and small nectarivorous species Anoura caudifer (E. Geoffroy, 1818), Glossophaga soricina (Pallas, 1766) and Choeroniscus minor (Peters, 1868).

\section{RESULTS}

A total of 310 individuals of nine species were caught, as follows: Artibeus obscurus $(\mathrm{n}=9)$, A. lituratus $(\mathrm{n}=31)$, A. fimbriatus $(\mathrm{n}=8), C$. perspicillata $(\mathrm{n}=200)$, S. lilium $(\mathrm{n}=32)$, P. lineatus $(\mathrm{n}$ $=5)$, A. caudifer $(\mathrm{n}=10)$, C. minor $(\mathrm{n}=10)$ and $G$. soricina $(\mathrm{n}=5)$. 


\section{Hourly activity}

There was no statistically significant difference in the hourly activity curves of $A$. obscurus and $A$. fimbriatus $(\mathrm{D}=0.1250$ $\mathrm{p}>0.05)$, A. lituratus and A. obscurus $(\mathrm{D}=0.500 ; \mathrm{p}>0.05)$, and $A$. fimbriatus and $A$. lituratus $(\mathrm{D}=0.625 ; \mathrm{p}>0.05)$ indicating that the three species of Artibeus presented the same general activity pattern: the highest peak in the first two/three hours of the night, with an activity decrease in the next hours (Fig. 2). A second peak for the three species was verified during the fifth hour interval.

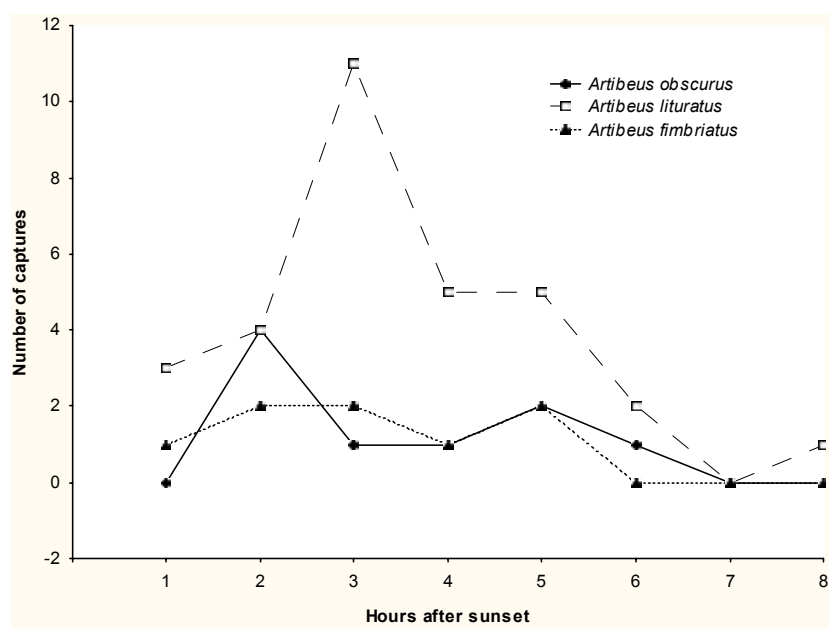

Figure 2. Hourly activity based on mist net captures of Artibeus species at the RPPN-MFA, Minas Gerais state, southeastern Brazil.

There was a significant differences between the activity curves of C. perspicillata and S. lilium ( $\mathrm{D}=0.750 ; \mathrm{p}<0.05$ ). Both had a higher peak of activity in the second hour of capture decreasing in the next hours, but Sturnira lilium exhibited also a second smaller peak in the fifth hour interval (Fig. 3). $P$. lineatus seems to begin its activity a little bit later, reaching the peak in the fourth hour, when most species were less active. There is a significant difference when compared with $C$. perspicillata $(\mathrm{D}=0.750 ; \mathrm{p}<0.05)$ but no difference when compared with $S$. lilium ( $=0.625 ; \mathrm{p}>0.05)$.

The nectarivorous $G$. soricina, A. caudifer e C. minor had different peaks of capture along the night (Fig. 4). Choeroniscus minor was more active during the second hour whereas $G$. soricina was during the fifth hour and $A$. caudifer in the fourth. Although the activity patterns of the three nectarivorous species may seem distinct (Fig. 4), no statistical significant difference was found when comparing pair of species: G. soricina and C. minor ( $\mathrm{D}=0.125 ; \mathrm{p}>0.05) ; G$. soricina and $A$. caudifer $(\mathrm{D}=0.375 ; \mathrm{p}>0.05)$, and $C$. minor and $A$. caudifer $(\mathrm{D}=0.250$; $\mathrm{p}>0.05)$.

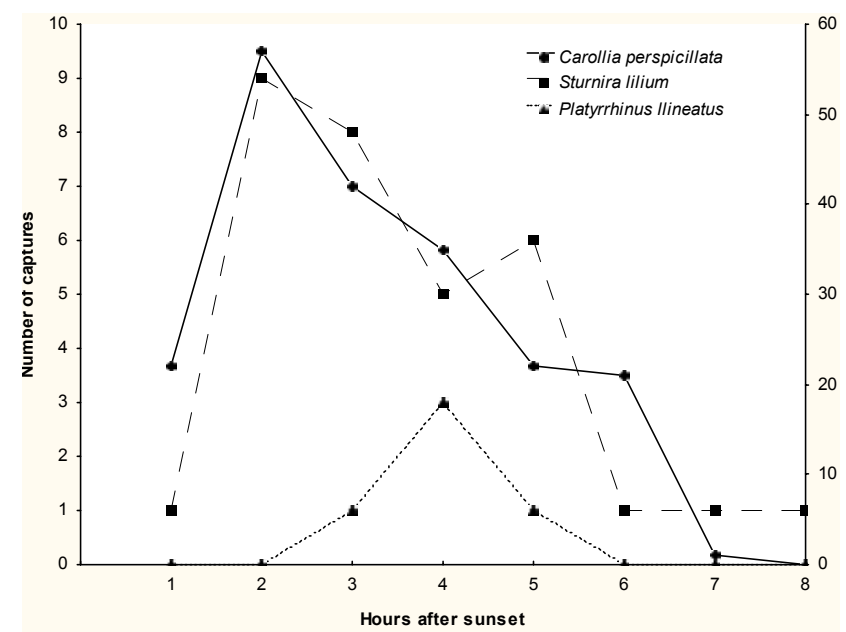

Figure 3. Hourly activity based on mist net captures of Carollia perspicillata (Y2), Sturnira lilium and Platyrrhinus lineatus at the RPPN-MFA, Minas Gerais state, southeastern Brazil.

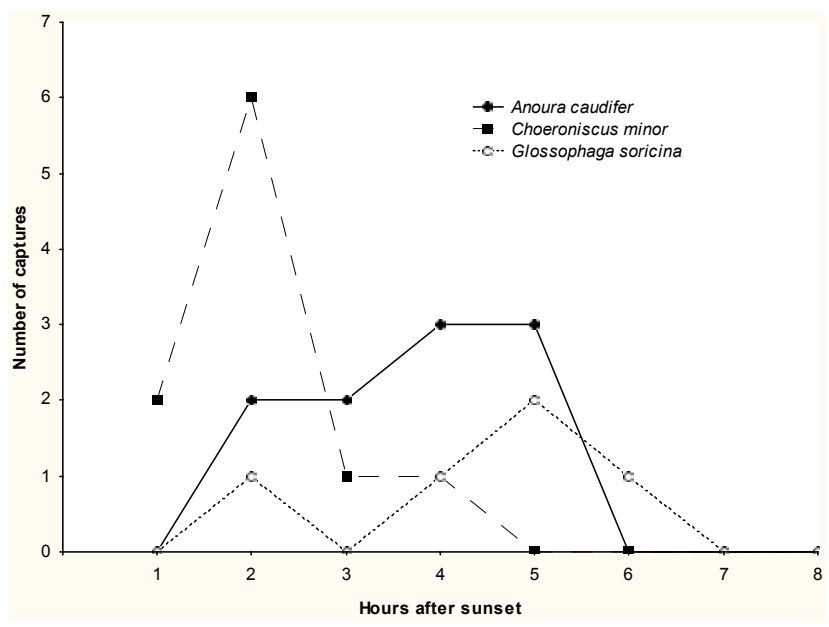

Figure 4. Hourly activity based on mist net captures of Anoura caudifer, Choeroniscus minor and Glossophaga soricina at the RPPNMFA Reserve, Minas Gerais state, southeastern Brazil.

\section{Monthly activity}

Monthly activity curves of these three species show no significant differences when compared with each other; $A$. lituratus and $A$. fimbriatus $(\mathrm{D}=0.272 ; \mathrm{p}>0.05) ; A$. obscurus and A. lituratus $(\mathrm{D}=0.363 ; \mathrm{p}>0.05) ; A$. fimbriatus and $A$. obscurus $(\mathrm{D}=0.090 ; \mathrm{p}>0.05)$. Most captures of A. lituratus (77.4\%), $A$. obscurus $(77.7 \%)$, and $A$. fimbriatus $(87.5 \%)$ occurred during the rainy season (October - March) (Fig. 5). However, ChiSquare Test showed no significant difference in activity considering the dry and rainy seasons for $A$. obscurus $\left(\chi^{2}=2.77\right.$;

Revista Brasileira de Zoologia 21 (2): 385-390, junho 2004 
$\mathrm{p}>0.05)$, but there are significant differences for $A$. fimbriatus $\left(\chi^{2}=4.50 ; \mathrm{p}<0.05\right)$ and A. lituratus $\left(\chi^{2}=11.64 ; \mathrm{p}<0.05\right)$. During the dry season Artibeus lituratus was found in May, August and September, A. obscurus was captured only in August, and A. fimbriatus in September.

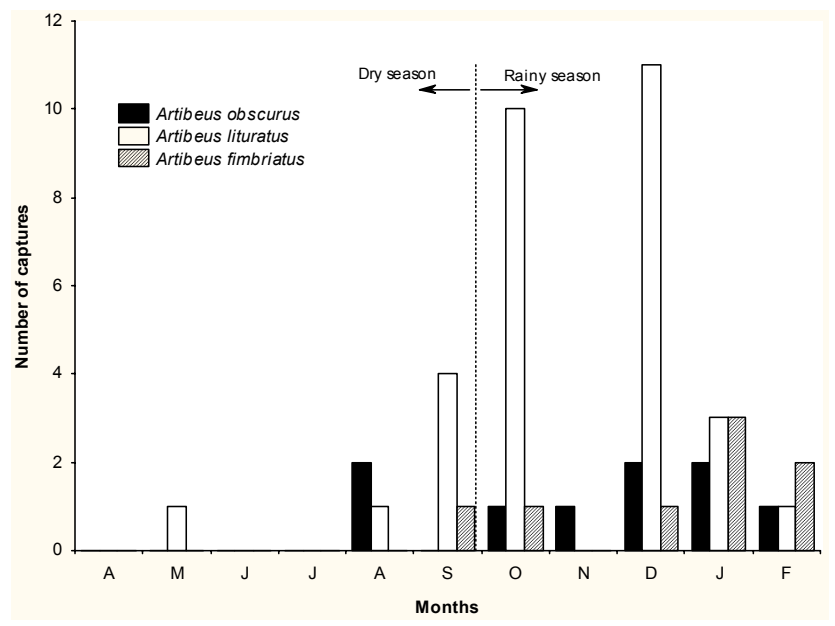

Figure 5. Monthly activity based on mist net captures of Artibeus species, showing dry and rainy seasons, at the RPPN-MFA, Minas Gerais state, southeastern Brazil.

For the middle sized frugivorous species, Carollia perspicillata (Fig. 6 - axis Y2) was the most frequent species throughout the eleven months. It showed two activity peaks, being more active during the dry season $\left(\chi^{2}=11.52 ; \mathrm{p}<0.05\right)$. Sturnira lilium, contrary to $C$. perspicillata, concentrated its activities in the rainy period $\left(\chi^{2}=8.0 ; \mathrm{p}<0.05\right)$. During the dry season months of May, July and September, S. lilium was absent, as well as in December, during the rainy season. In fact, when comparing annual activity curves of $S$. lilium and $C$. perspicillata we verified a significant difference $(\mathrm{D}=0,636$; $\mathrm{p}<$ 0.05). The other frugivorous species, $P$. lineatus demonstrated no preference for any season (Fisher's Exact Test $p=0.6429$ ) and its monthly activity curve presented significant difference in relation to $C$. perspicillata $(\mathrm{D}=0,909 ; \mathrm{p}<0.05$ ) but no difference in relation to $S$. lilium ( $\mathrm{D}=0.454 ; \mathrm{p}>0.05)$.

Most captures of the nectarivorous species $G$. soricina, A. caudifer and C. minor occurred in May and June, during the dry season (Fig. 7). However, we found no statistically significant difference between frequency of captures in dry and rainy season for $A$. caudifer $\left(\chi^{2}=1.60 ; \mathrm{p}>0.05\right)$ and $G$. soricina $\left(\chi^{2}=0.20 ; \mathrm{p}>0.05\right)$, but there is a difference for C. minor $\left(\chi^{2}=\right.$ $6.40 ; \mathrm{p}<0.05)$. There was no significant difference between monthly activity curves for nectarivorous species: $A$. caudifer and C. minor ( $\mathrm{D}=0.090 ; \mathrm{p}>0.05), A$. caudifer and $G$. soricina $(\mathrm{D}=0.181 ; \mathrm{p}>0.05)$, and C. minor and G. soricina $(\mathrm{D}=0.181$; $\mathrm{p}>0.05)$.

Revista Brasileira de Zoologia 21 (2): 385-390, junho 2004

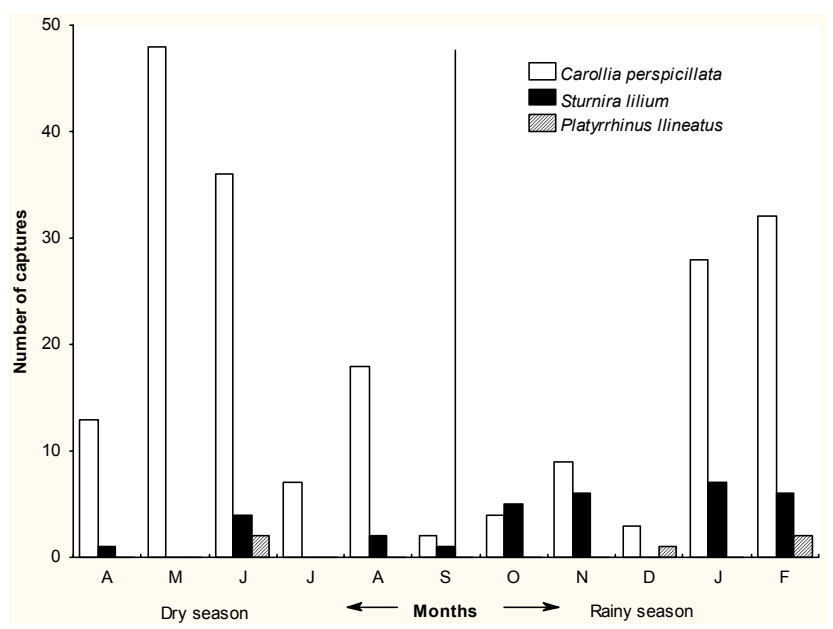

Figure 6. Monthly activity based on mist net captures of Carollia perspicillata (Y2), Sturnira lilium, and Platyrrhinus lineatus, showing dry and rainy seasons, at the RPPN MFA, Minas Gerais state, southeastern Brazil

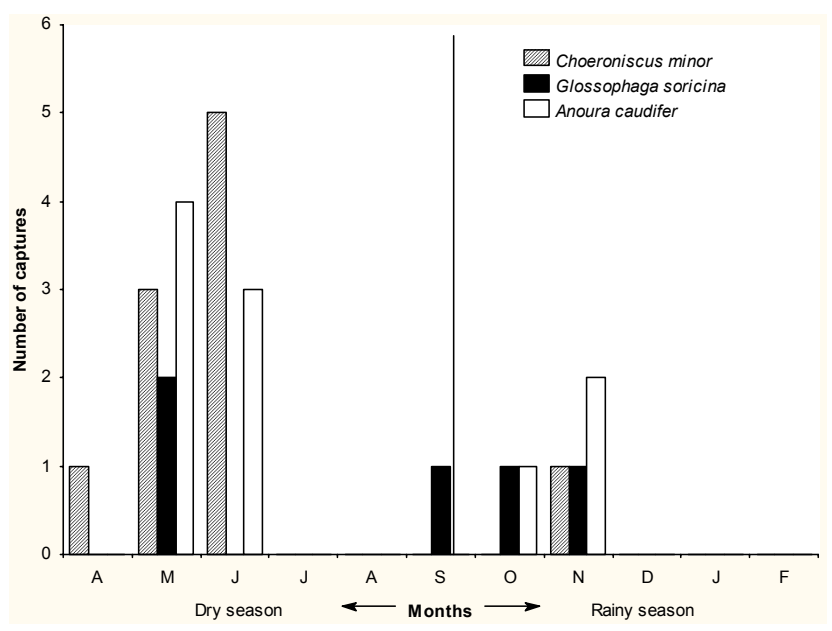

Figure 7. Monthly activity based on mist net captures of Anoura caudifer, Choeroniscus minor and Glossophaga soricina, showing dry and rainy seasons, at the RPPN-MFA, Minas Gerais state, southeastern Brazil.

\section{DISCUSSION}

\section{Hourly activity patterns}

Although we found a significant difference in hourly activity patterns of C. perspicillata and S. lilium, and C. perspicillata and $P$. lineatus, this cannot be invoked as resource partitioning strategy, since the fruits taken in the beginning of the night cannot be replaced by others in a short period of time. The idea of reduction in resource competition, due to hourly activity divergence, can only be acceptable for insectivorous and nectarivorous bat species, which explore resources quickly renewable (MARINHO- 
Filho \& SAZIMA 1989). Fruits taken in the beginning of the night cannot be replaced by others in a short period of time.

The pattern found for all frugivorous species is in accordance with other studies on this subject in different regions of the Neotropics (e.g. Brown 1968, la Val 1970, Erkert 1982, Reis 1984, Bernard 2002, Pedro \& Taddei 2002) who observed that frugivorous bat species tend to maintain some activity throughout the night with a peak in the first hours after dusk, characterizing an unimodal curve. Although bats were not sampled at the latest hours of the night, a pilot study, as well as the data presented here, indicated a strong reduction in bat activity around 5-6 hours after the sunset. The same pattern was found for the nectarivorous. The pressure caused by the reduction in the number of ripe fruits and nectar production after some hours of consumption, by frugivores and nectarivorous, may explain the general trend observed in this, and other studies, for frugivorous and nectarivorous bats, to concentrate their activity in the early period of the night.

\section{Monthly activity patterns}

In tropical regions, the distribution and abundance of frugivorous and nectarivorous species are associated with the temporal and spatial availability of certain fruits and flowers (Fleming 1986, Marinho-Filho 1991). Usually the dry and rainy seasons define a blossoming and a fruiting seasonal pattern due to the higher flower production during the dry season, whereas most fruit production occurs in the rainy season (Heithaus et al. 1975). In the present study, it was observed that the three nectarivorous species were more frequent in the first half of the dry season, with a smaller second peak occurring in the first half of the rainy season.

Studies on plant phenology at RPPN-MFA's (e.g. RIMOLI \& ADEs 1997) show an increase in fruit production during the rainy season and a decrease during the dry season, when many species are flowering. Marinho-Filho \& Sazima (1989) found nectarivorous bats (A. caudifer) most active during the dry season, when flowering was more intense at Serra do Japi, also an Atlantic Forest site, in São Paulo state. Pedro \& Taddei (2002) found two nectarivorous species (A. caudifer and G. soricina) mainly in the beginning of the rainy season in their Cerrado study site, where there is a flowering peak in September-October, at the end of the dry season and beginning of rainy season (Oliveira \& Paula 2001). It seems that activity of nectarivorous species during the dry season associated with flowering peaks is an expected general pattern.

According to TADDEI (1996), there are 14 predominantly nectarivorous bat species in Brazil. The glossophagines $G$. soricina, A. caudifer, and A. geoffroyi are among the most frequent species. Anoura caudifer is one of the most important pollinating agents of several species in the Atlantic rainforest (SAZIMA et al. 1999), and at the RPPN-MFA its diet was based on pollen and nectar. G. soricina showed a tendency to begin and maintain its activity a little bit later than those of $A$. caudifer and C. minor. The hourly activity pattern observed for these species at the RPPN-MFA is also different from that verified by Pedro \& TAdDei (2002) at Uberlândia, Minas Gerais. They observed an earlier peak of activity for $A$. caudifer in comparison with $G$. soricina. Although no statistical difference among hourly activity patterns for the nectarivorous species was found, the concentration of the activity of $C$. minor in the very beginning of the night, when the other two nectarivorous species are less active, and the decrease in C. minor's activity when the occurrence frequency of $G$. soricina and $A$. caudifer raise, may suggest a resource partitioning within the nectarivorous guild.

Most captures of $G$. soricina, the lesser specialized nectarivorous species, were done during three months of the rainy season. Only a few captures occurred in the dry season. These data indicate that $G$. soricina can shift to a more frugivorous diet as already observed in Brazil (Pedro \& TAdDei 2002, Zortéa 2003) and Central America (Fleming et al. 1972, Heithaus et al. 1975, Rivas-Pava et al. 1996, Stoner 2001).

Sturnira lilium and Platyrrhinus lineatus are most active in the wet season which correspond to the period of greater availability of fruits at the study site (RIMOLI \& ADEs 1997), as already observed by other authors (e.g. Pedro \& TAdDei 2002, Marinho-Filho \& Sazima 1989, Bernard 2002). Although Carollia perspicillata was found almost during all sampling, most captures at the RPPN-MFA occurred during the dry period. It is important to notice that $C$. perspicillata is more active exactly when $S$. lilium is less frequent and vice-versa.

Marinho-Filho \& Sazima (1989) observed a peak of activity for Artibeus lituratus during the dry season at Serra do Japi but, in contrast to our results, they also found Artibeus along the rainy season. STONER (2001) found species of Artibeus active along the year with a peak of $A$. lituratus in the dry period. Artibeus species are known to feed mainly on Ficus and Cecropia, fruits that are also very important to monkey populations of Alouatta guariba (Humboldt, 1812) and Brachyteles hypoxanthus in the area (STRIER 1992). Artibeus species in the RPPN-MFA were present only in the end of the dry season and along all the rainy months. Two hypotheses can explain the absence of these species during the dry season: 1) these bats are in small populations in the area and were not captured due to their low number; 2 ) there is a dynamic among fragments in the region and the bats come and go from one fragment to another when food or shelter is available. The possibility of a strong competition between bats and monkeys at RPPN-MFA for the available fruits during the dry season, when these monkeys eat flowers, leaves, green and ripe fruits, perhaps inducing the bats to migrate to other fragments within the region in search for food, should be investigated.

Considering that the RPPN-MFA is a conservation unit designed to protect remnant primate populations in the region, and these animals occur in high numbers at this RPPN, this system may prove to be an interesting site to study the interactions among frugivores and the consequences of focal species management to the whole community.

Revista Brasileira de Zoologia 21 (2): 385-390, junho 2004 


\section{ACKNOWLEDGMENTS}

Thanks to Martin, Riva, Rodrigo, and André for their assistance during the field work and to Jairo and Lada for their help and hospitality during my stay at the RPPN Miguel Feliciano Abdala. Thanks to E.M. Veado and Ricardo B. Machado who helped with mapping, field work, photos, fun and coffee. Dr. V.A. Taddei kindly confirmed species identification. Thanks to G.A.B. Fonseca for helping with field equipment and logistic. The CNPq provided graduated scholarship (MSc) to L.M.S.A. and financial support to J.M.F. (PROC.30591/86-1). Thanks also to F. Passos and other two anonymous referees for their helpful comments that greatly improved this manuscript.

\section{REFERENCES}

BERNARD, E. 2002. Diet, activity and reproduction of bat species (Mammalia: Chiroptera). Revista Brasileira de Zoologia, Curitiba, 19(1): 173 -188.

Brown, J.H. 1968. Activity patterns of some Neotropical bats. Journal of Mammalogy, Provo, 45: 635-636.

ERKERT, H.G.1982. Ecological aspects of bat activity rhythms, p. 201-242. In: T.H. Kunz (Ed.). Ecology of Bats. New York, Plenum Press, 425p.

FLEMING, T.H. 1986. Opportunism vs. specialization: the evolution of feeding strategies in frugivorous bats, p. 105-118. In: A. Estrada \& T.H. Fleming (Eds). Frugivores and seed dispersal. Dordrecht, W. Junk Publishers, 392p.

— 1988. The short-tailed fruit bat: a study in plantanimal interactions. Chicago, University of Chicago Press,

Fleming, T.H., E.T. Hooper \& D.E. Wilson. 1972. Three Central American bat communities: structure, reproductive cycles and movement patterns. Ecology, London, 53: 555-569.

Heithaus, E.R.; T.H. Fleming \& P.A. Opler. 1975. Foraging patterns and resource utilization in seven species of bats in a tropical forest. Ecology, London, 56: 841-854

Holdridge, L.R. 1967. Life zone ecology. San José, Tropical Science Center, 206p.

Iвge. 1977. Geografia do Brasil. Região Sudeste. Rio de Janeiro, Fundação Instituto Brasileiro de Geografia Estatística, 667p.

LA VAL, R.K. 1970. Banding returns and activity periods of some Costa Rican bats. Southwestern Naturalist, Norman, 15: $1-10$.

LA VAL, R.K. \& H.S. Fitch. 1977. Structure, movements and reproduction in three Costa Rican bat communities. Occasional Papers of the Museum of Natural History, Kansas, 69: 1-28.

MARINHo-FilHo, J.S. 1991. The coexistence of two frugivorous bats and the phenology of their food plants in Brazil. Journal of Tropical Ecology, London, 7 (1): 59-67.

MARINHO-FILHo, J.S. \& I. SAzima. 1989. Activity patterns of six Phyllostomidae bat species in Southeastern Brazil. Revista Brasileira de Biologia, Rio de Janeiro, 49 (3): 777-782.

Muller, M.F. \& N.R. ReIs.1992. Partição de recursos alimentares entre quatro espécies de morcegos frugívoros (Chiroptera, Phyllostomidae). Revista Brasileira de Zoologia, Curitiba, 9 (3/4): 345-355.

Norberg, U.M.; T.H. Kunz; J.F. Steffensen; Y. Winter \& O. von Helversen. 1993. The cost of hovering and forward flight in a nectar-feeding bat, Glossophaga soricina, estimated from aerodynamic theory. Journal of Experimental Biology, Cambridge, 182: 207-227.

Oliveira, P.E.A.M. \& F.R. de Paula. 2001. Fenologia e biologia reprodutiva de plantas de matas de galeria, p. 303-334. In: J.F. Ribeiro; C.E.L. Fonseca \& J.C. Souza-Silva (Eds). Cerrado; Caracterização e recuperação de matas de galeria. Planaltina, Embrapa Cerrados, 899p.

Pedro, W.A. \& V.A. TAddei. 2002. Temporal distribution of five bat species (Chiroptera, Phyllostomidae) from Panga Reserve, south-eastern Brazil. Revista Brasileira de Zoologia, Curitiba, 19: 951-954.

ReIs, N.R. 1984. Estrutura de comunidades de morcegos na região de Manaus, Amazonas. Revista Brasileira de Biologia, Rio de Janeiro, 44: 247-254

Rimoli, J. \& C. Ades. 1997. Estratégias de forrageamento de um grupo de Muriquis (Brachyteles arachnoides, Primates, Cebidae) da Estação Biológica de Caratinga, Minas Gerais, p. 39-57. In: S.F. Ferrari \& H. Schneider (Eds). A primatologia no Brasil 7. Belém, Editora Universitária, UFPA, 220p.

Rivas-Pava, P.; P. SANChes-Palomino \& A. Cadena. 1996. Estructura trófica de la comunidad de quirópteros em bosques de galeria de la serrania de la Macarena (Meta-Colombia), p. 237248. In: H.H. GENOWAYS \& R.J. BAKER (Eds). Contributions in Mammalogy: a memorial volume honoring Dr. J. Knox Jones Jr. Lubbock, Museum of Texas Tech University, 315p.

Sazima, M.; S. Buzato \& I. SAzIma. 1999. Bat pollinated flower assemblages and bat visitors at two Atlantic forest sites in Brazil. Annals of Botany, Bristol, 83: 705-712.

STONER, K.E. 2001. Differential habitat use and reproductive patterns of frugivorous bats in tropical dry forest of north western Costa Rica. Canadian Journal of Zoology, Ottawa, 79: 1626-1633.

STRIER, K.B. 1992. Faces in the Forest: the endangered muriqui monkeys of Brazil. New York, Oxford University Press, 138p.

TADDEI, V.A. 1996. Sistemática de quirópteros. Boletim Instituto Pasteur, São Paulo, 1 (2): 3-15.

Trajano, E. 1985. Ecologia de populações de morcegos cavernícolas em uma região cárstica do sudeste do Brasil. Revista Brasileira de Zoologia, Rio de Janeiro, 2: 255-320.

ZAR, J.H. 1984. Biostatistical Analysis. New Jersey, Prentice Hall, Engewood Cliffs, $2^{\text {nd }}, 718 \mathrm{p}$.

ZORTÉA, M. 2003. Reproductive patterns and feeding habits of three nectarivorous bats (Phyllostomidae: Glossophaginae) from the Brazilian Cerrado. Brazilian Journal of Biology, São Carlos, 63 (1): 159-168.

Received in 29.VIII.2003; accepted in 08.VI.2004. 